\title{
Moisture expansion associated to secondary porosity: an example of the Loseros Tuff of Guanajuato, Mexico
}

\author{
Rubén López-Doncel · Wanja Wedekind • \\ Reiner Dohrmann $\cdot$ Siegfried Siegesmund
}

Received: 5 June 2012/ Accepted: 12 June 2012/Published online: 1 July 2012

(c) The Author(s) 2012. This article is published with open access at Springerlink.com

\begin{abstract}
The old mining city of Guanajuato in middle Mexico preserves one of the most important historical legacies in colonial buildings, the UNESCO declared the city World Heritage Site in 1988. Practically all the colonial constructions were built with natural stones from the neighbourhood, of which stands a greenish to reddish vulcanite, called Loseros Tuff. Although the Loseros Tuff is widely used in historical buildings in the city. It shows significant deterioration and weathering effects, principally in the parts where the tuff shows a coarse grain size. The petrographic, petrophysical, mineralogical and geochemical properties of the Loseros Tuff were analysed in order to determine the causes, effects, behaviour and response to deterioration of this volcanic rock. The results of the investigations suggest that in addition to the parameters like the grain size and the porosity properties, the pore radii distribution is decisive for the effectiveness of porosity and the water transport into the rock. It is recognized that once the liquid water invades the rock the dissolution of the matrix occurs, which is accompanied by a sudden moisture expansion favoured by the newly formed secondary porosity and the high content of expandable clay minerals.
\end{abstract}

R. López-Doncel $(\bowtie)$

Geological Institute, Autonomous University of San Luis Potosí,

San Luis Potosí, Mexico

e-mail: rlopez@uaslp.mx

W. Wedekind $\cdot$ S. Siegesmund

Geoscience Centre of the University Göttingen,

Göttingen, Germany

R. Dohrmann

Bundesanstalt für Geowissenschaften und Rohstoffe,

Hannover, Germany
Keywords Tuff · Moisture expansion · Porosity · Guanajuato

\section{Introduction}

The old mining city of Guanajuato in middle Mexico belongs to the most important historical cities of Latin America, which preserves one of the most important historical legacies in colonial buildings. The establishment of this city, which later would become one of the most important cities of the New Spain, was basically due to the discovery of the silver and gold ore deposits that initiated the mining industry in 1548, which resulted in the legal foundation of the town of Santa Fe de Guanajuato in 1570. The result of the wealth spread around the city was reflected in beautiful buildings that were constructed with natural rocks. Mainly during the seventeenth, nineteenth and early twentieth centuries a number of buildings were erected that would play important roles during the battles for independence of Mexico. Since Guanajuato had become an important economic, cultural and religious centre in Mexico, it has shown a remarkable growth during the twentieth century, and thus increasing the preservation of old churches and the construction of notable buildings such as the Teatro Juarez and the building of the University Guanajuato (Fig. 1a, b); the city was declared in 1988 World Heritage Site by the UNESCO. Practically all the colonial constructions were built with natural stones from the neighbourhood, of which stands a greenish to reddish vulcanite, called Loseros Tuff.

\section{Utilization and deterioration}

The utilization of the Loseros Tuff as natural building material includes filler rock for roads, walls, bridges and 

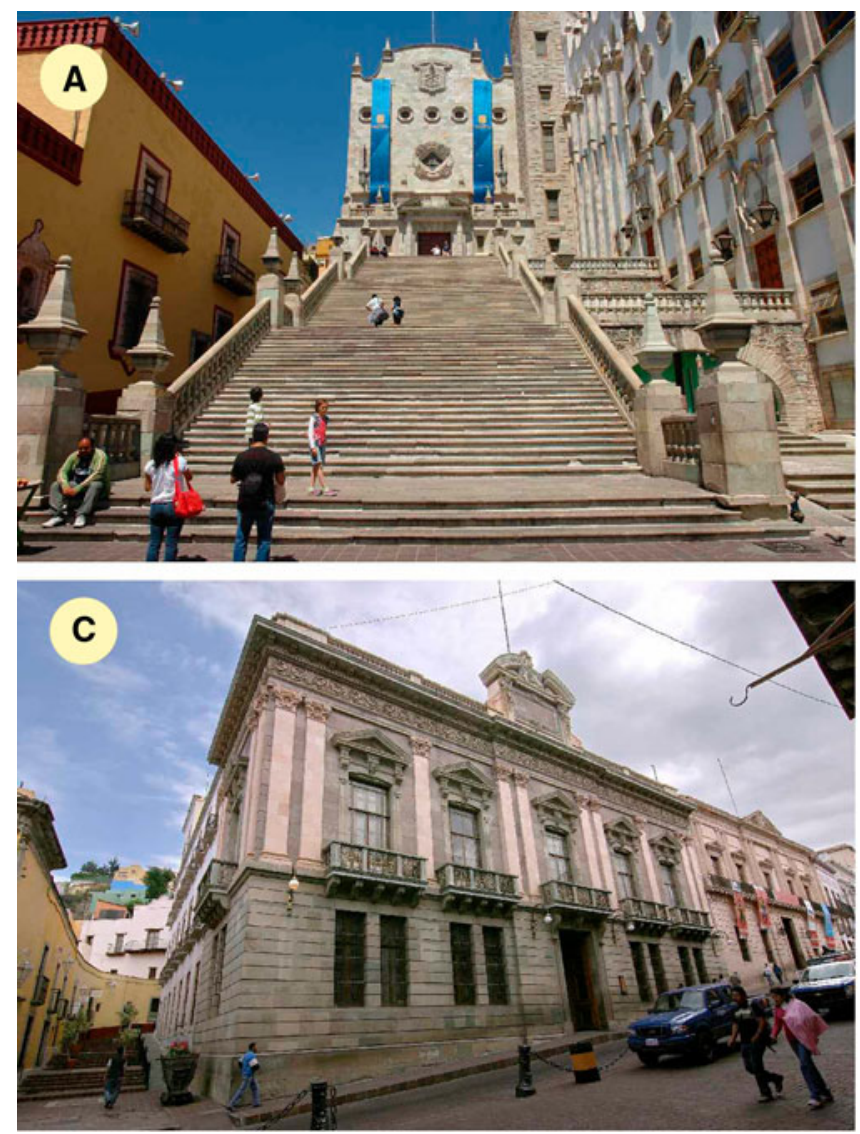

Fig. 1 Historic buildings erected with the Loseros Tuff in the city of Guanajuato. a Staircase and facade of the central building of the University of Guanajuato. b Juarez Theater in the centre of the city, the columns and the facade were built entirely with the studied tuff.

especially the construction of a complex system of underground tunnels that cross the city of Guanajuato (Fig 1d). When the Loseros Tuff is cut along the lamination ( $X$-axis), or it is finely reworked perpendicular to the lamination it is used as fine masonry for the most important cultural, religious and governmental buildings (Fig. 1c). In the nineteenth century and early twentieth century the Loseros Tuff found a widespread use as a popular material especially for tomb monuments in central Mexico. Examples can be found in Guadalajara (Fig. 2c), as well as in Mexico City.

Although the Loseros Tuff is widely used, it shows significant deterioration and weathering effects, first of all by scaling parallel to the bedding but also by the scaling independently of the bedding (Fig. 2c), crumbling (Fig. 2b, d) and flaking (Fig. 2a). These destructive phenomena mostly are found in areas of the building where moisture and water are permanently or temporarily present such as columns, fountains, balconies or external staircases. A detailed view of the deterioration of the rock directly in the construction clearly shows that the horizons formed by
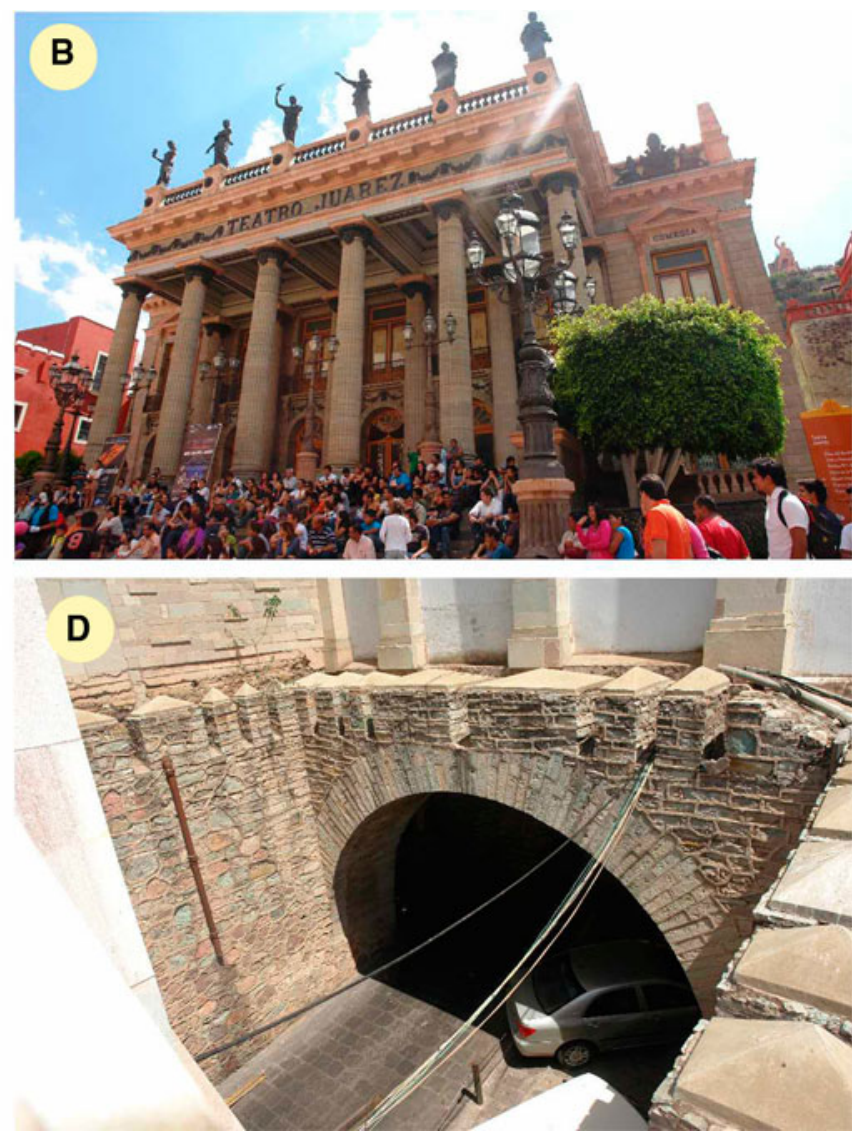

c Legislative Palace whose facade is built with cuts parallel to the lamination ( $X$-axis) of the Loseros Tuff. d Entrance to one of the underground tunnels that cross the city

coarser grain sizes are more affected than those of finer fractions. It is also evident, that the coarser horizons have an apparent higher porosity, because the pores reach the grain size of sand, or even bigger. Also the binding cement, relocation processes and the concentration of this cement near the surface seems to play a role especially in forming of scales.

The aim of this study is to determine the petrographic, petrophysical, mineralogical and geochemical properties of the Loseros Tuff. The main goal is to provide information about the influence of porosity, pore radii distribution, grain size and chemical composition on the causes, effects, behaviour and response to deterioration of this volcanic rock.

\section{Materials and methods}

Based on the macroscopic observation a marked difference in the type and form of damage was identified. The hypothesis is that the integrity of the tuff is probably 

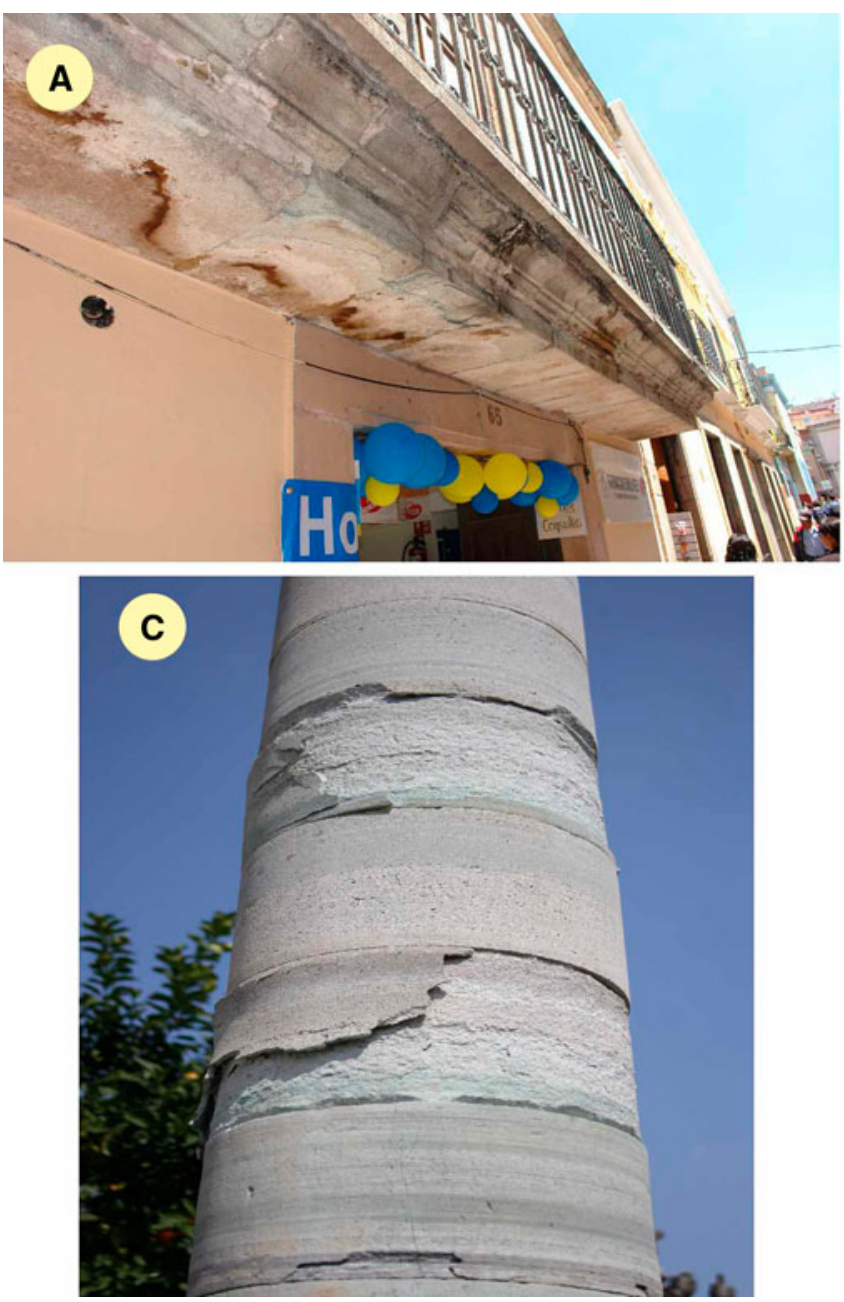

Fig. 2 Appearance of the different damage and deterioration types observed in the Loseros Tuff. a Flaking in the lower parts of a balcony. b Crumbling in the bars of the staircase of the university.

affected by the particle (grain) size and by the apparent porosity. In order to analyse these differences two different varieties of the tuff were studied: (1) a coarse-grained specimen, which has been separated into seven different horizons appointed $1 \mathrm{~g}-7 \mathrm{~g}$ (Fig. 3). And (2) a fine-grained specimen, that was separated into five horizons called $1 \mathrm{f}-5 \mathrm{f}$ (Fig. 4). All the coarse-grained horizons have a grain size that ranges from fine sand-size (1g and $2 \mathrm{~g}$ ), sand-size $(3 \mathrm{~g}$ and $6 \mathrm{~g}$ ), coarse sand-size ( $5 \mathrm{~g}$ and $7 \mathrm{~g}$ ) to very coarse sandsize, and to very fine pebbles (granules) (4g). The horizons of the fine-grained variety vary from very fine sand ( $4 \mathrm{f}$ and 5f) to silt grain size (1f and 3f), and locally even clay fraction (2f).

The petrographic analyses were performed on oriented thin sections of the coarser and finer species and studied under a polarizing microscope. Mineralogical and geochemical analyses were performed using XRD (whole rock samples, and oriented slides of clay fractions $<2 \mu \mathrm{m}$ ),
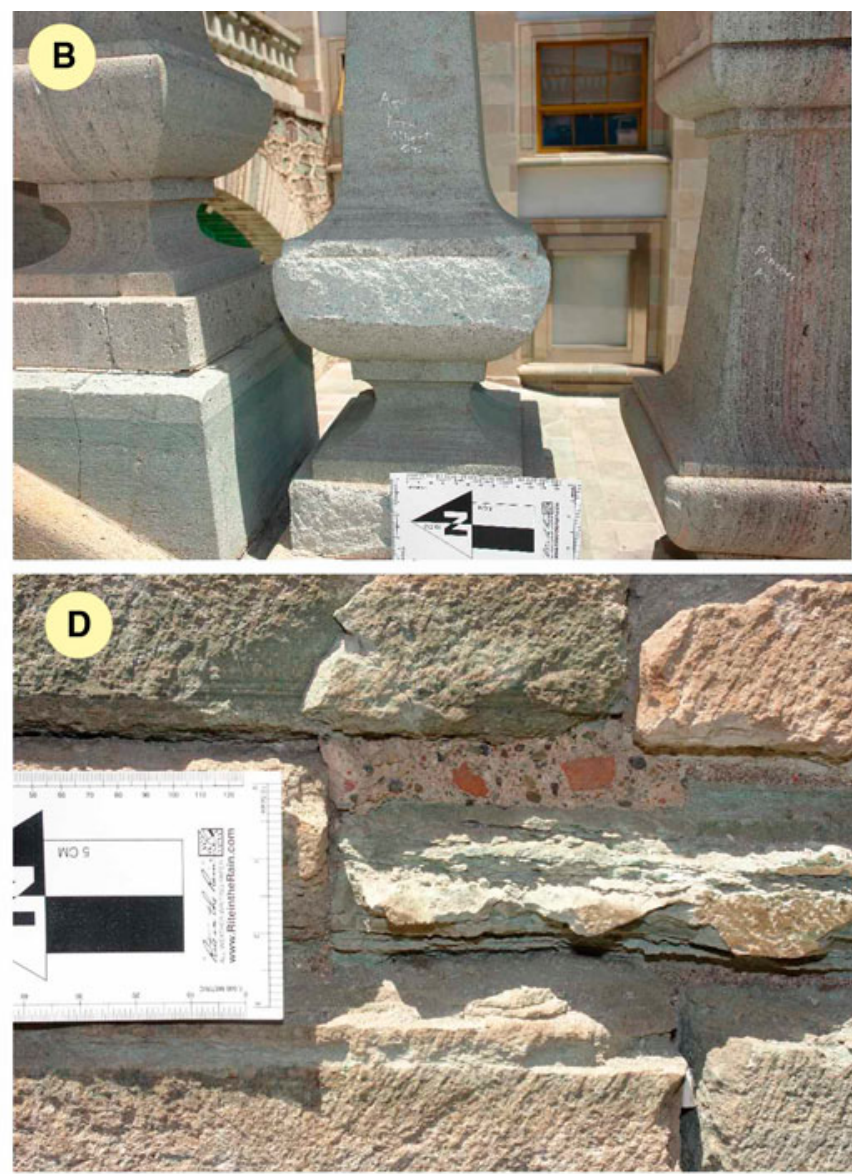

c Scaling perpendicular to lamination in a grave in the cemetery of Guadalajara. d Crumbling in a filler rock into the tunnel wall

along with XRF, elemental carbon and sulphur analysis, and CEC analyses (compare Rüdrich et al. 2011a, b).

Hydrostatic weighing was carried out to acquire the matrix and bulk density as well as the porosity of each horizon. Water uptake coefficient ( $w$ value) was determined with help of the capillary suction in a closed cabinet while weighing. The water vapour diffusion resistance value $(\mu)$ was measured using the wet-cup method. The pore radii distribution was determined using mercury injection porosimetry (Brakel et al. 1981, see also Siegesmund and Snethlage 2011).

The hydric and hygric expansion of each horizon was measured on cylindrical samples (diameter $15 \mathrm{~mm}$, length $100 \mathrm{~mm}$ ). For hydric expansion measurements the cylinders were completely immersed in distilled water (water saturated). For hygric dilatation analysis an initial relative humidity (RH value) of $20 \%$ was used, which was increased gradually to a $\mathrm{RH}$ value of $95 \%$. The 

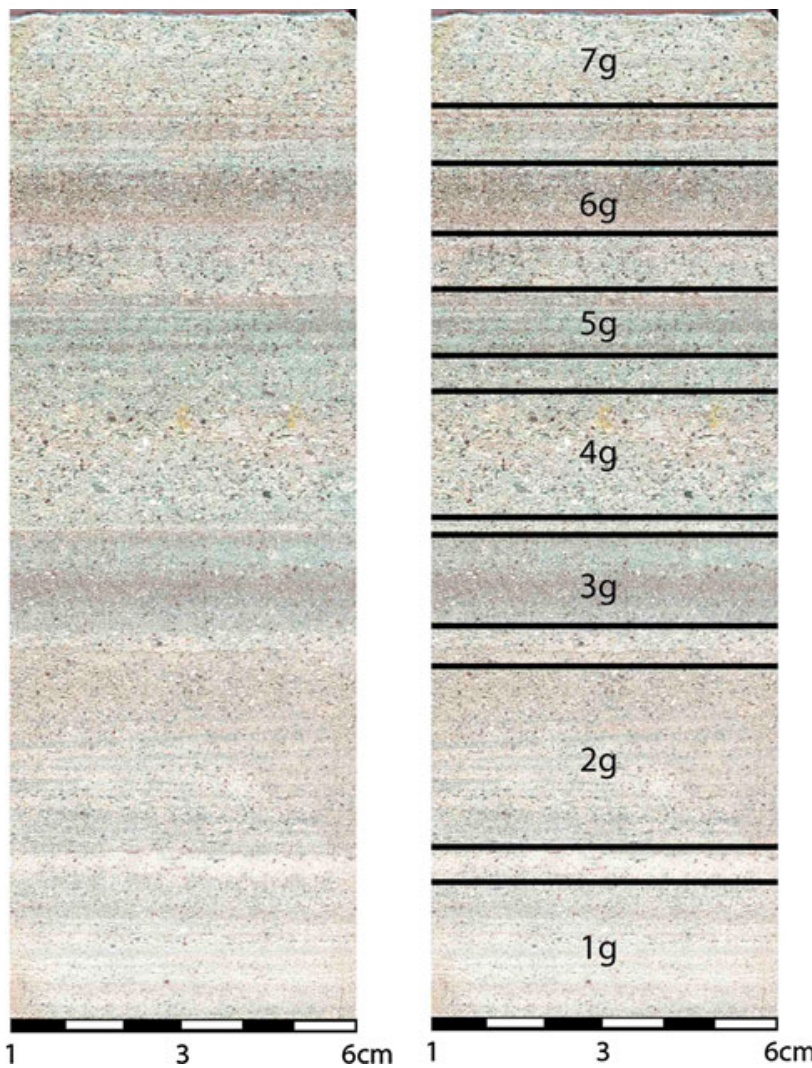

Fig. 3 Appearance of the coarse variety of Loseros Tuff and its separation in the different studied horizons
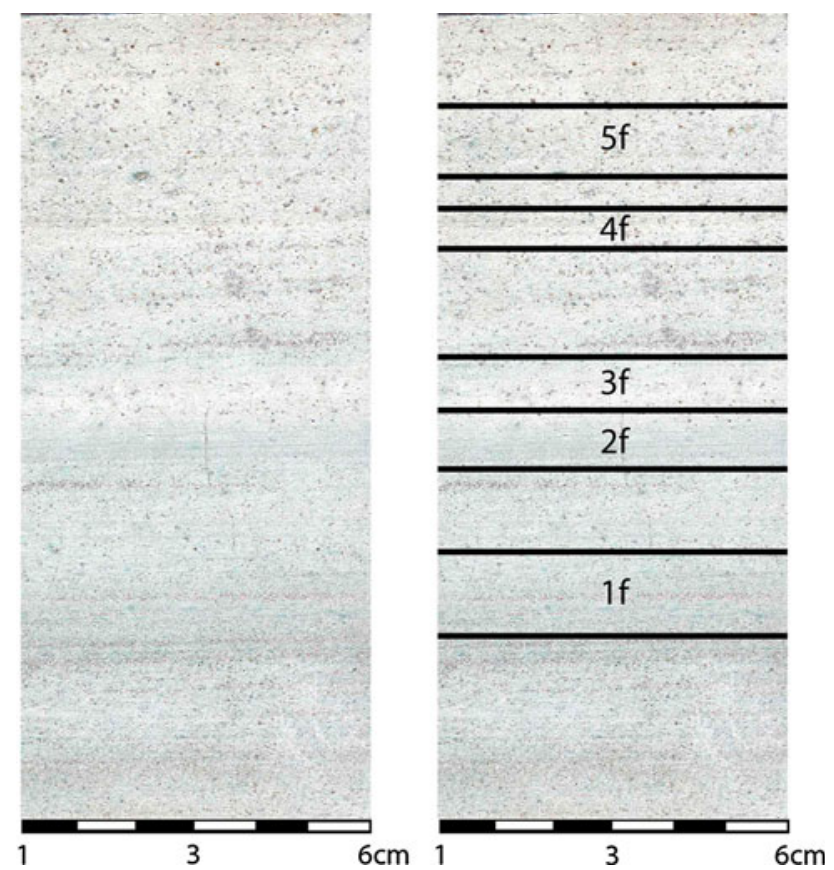

Fig. 4 Appearance of the finer variety of Loseros Tuff and its separation in the different studied horizons temperature was kept constant at $30{ }^{\circ} \mathrm{C}$ during the whole experiment.

Cylindrical samples with co-planar end-faces of $50 \mathrm{~mm}$ in diameter and $50 \mathrm{~mm}$ in length and $40 \mathrm{~mm}$ in diameter and $20 \mathrm{~mm}$ in length, respectively, were used for the compressive and tensile strength tests. The compressive strength load was realized with the help of a servohydraulic testing machine with a stiff testing frame $\left(3,000 \mathrm{kN} / \mathrm{mm}^{2}\right)$ and a load range up to $300 \mathrm{kN}$. The tensile strength measurements were determined by means of the "Brazilian test".

\section{Geological settings, petrography and mineralogy}

The Loseros Formation belongs to the Cenozoic volcanic rocks that form the Sierra de Guanajuato Area. This area is divided in two main rock successions. A succession that represents the basement composed principally of volcanic sedimentary sequences of Jura to Upper Cretaceous ages. These rocks are the oldest outcropped units in this region. These Mesozoic rocks belong to the so-called "Mesozoic Basement or Basement Complex of the Sierra de Guanajuato" (Ortiz-Hernández et al. 1992, also called "Guanajuato volcanic arc" for Monod et al. 1990). A second succession is overlying the Mesozoic sequence. Here more than 2,500 m of Tertiary to Quaternary volcanic rocks are outcropped, which show diverse chemical compositions, varying from basaltic, andesitic to rhyolitic. The extrusions of these Cenozoic volcanites are associated to the extensional tectonic at the end of the Laramide Orogeny in west and middle Mexico (Nieto-Samaniego et al. 1992).

The Loseros Tuff is a felsic vulcanoclastic rock that consists of well-sorted, sand-sized crystals and detrital rock fragments, which are embedded in an ash-rich altered groundmass. The Loseros Tuff appears in a wide variety of colour shades, which can range from reddish brown, pink, green and even white, but undoubtedly the green variety is the most requested and used. The grain size can also locally vary from gravel (granule), up to the clay fraction but the sand-grain size dominates. Loseros Tuff is a volcanic pyroclastic rock (Fisher 1961; Fisher and Schmincke 1984; Le Maitre et al. 2004) with a significant amount of epiclastic detritic material protruding pseudo-stratification with preferably normal gradation composed of 5 to 40- to 50-cm-thick layers (locally accretional lapilli layers thicker than $1 \mathrm{~m}$ ). Together with the lamination there are a series of very characteristic sedimentary structures, as cross-lamination, ripples, flame and cut-and-fill structures, etc.

Edwards (1956) noted that the majority of the grains are quartz, plagioclase and volcanic lithic fragments. In the thin section the Loseros Tuff shows a glassy matrix, which 
in polarized light appears almost completely opaque and its texture ranges from hypocrystalline to holohyaline. The recognized crystals are altered angular to subhedral plagioclase, angular quartz, and also altered biotite flakes (Fig. 5) (see also Wedekind et al., this issue). Likewise under the microscope it is possible to recognize "fissibilitylike" laminae, due to intercalations of fine sand and the clay fraction.

XRD analysis showed a significant amount of $\mathrm{CaCO}_{3}$ (calcite) that under the microscope is recognized as cement in the matrix. Observations on thin sections evidence that the remarkable greenish coloration of the tuff comes from a large number of small albite crystals with altered appearance (initially stage of transformation to clay minerals, Figs. 5 and $7 \mathrm{a}$ ) and also recognizable is that the matrix is made up also of volcanic glass, which shows different stages of devitrification. This green colour was not recognized in the matrix. Buchanan (1980) attributes the greenish coloration of this tuff to alteration (chloritization)

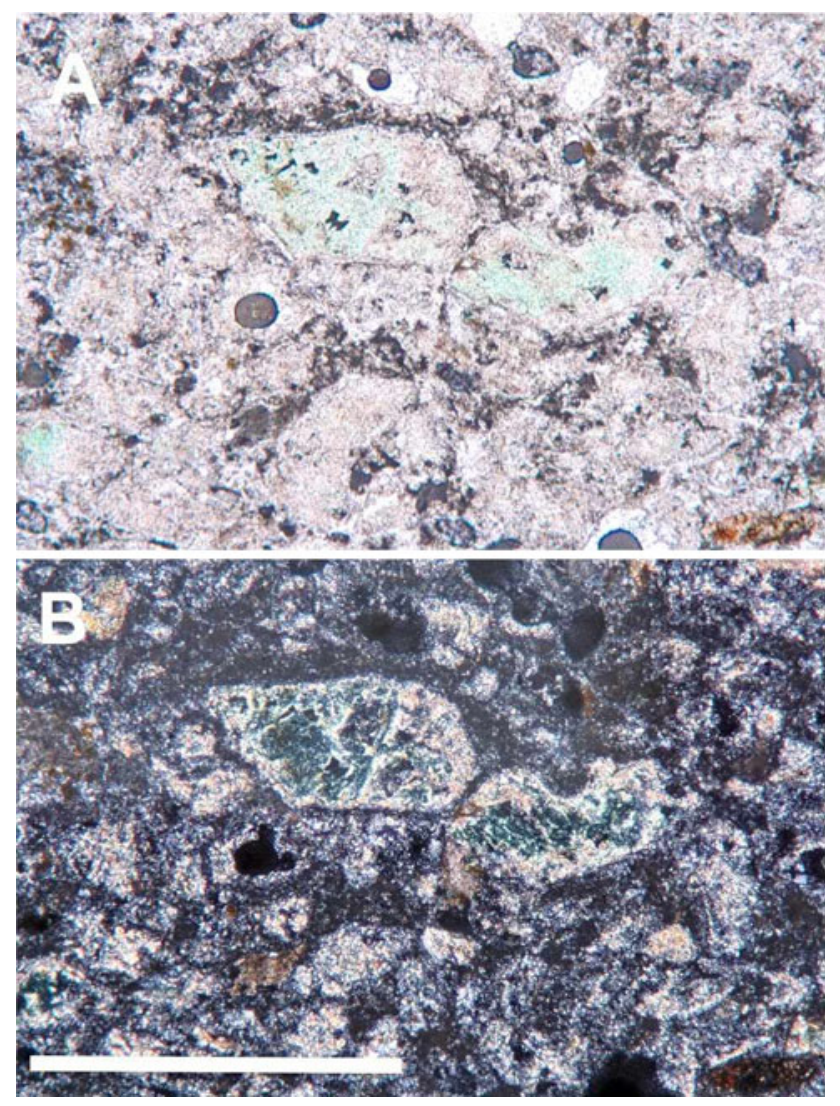

Fig. 5 Thin section photomicrographs of the studied tuff. Above the green coloration of an altered albite crystal (centre of image, compare with Fig. 7a) is recognizable in natural light. The matrix consists of poorly recognizable calcite, volcanic glass and small quartz crystals. Below the same sample under polarized light shows that the matrix is made up of opaque components (volcanic glass) with small crystals of calcite (crystals with third-order colours) and the altered plagioclase, that show rare interference colour. $\times 10$, scale bar $0.2 \mathrm{~mm}$ of the lithic fragments, but our geochemical analyses do not show the presence of chlorite in the Loseros Tuff.

Wedekind et al. (this issue) noted: "the matrix has more than $20 \%$ calcite and contains also kaolinite, however most common are the dioctahedral clay minerals illite plus $\mathrm{R} 3$ ordered illite(0.95)-smectite mixed layers which add up to a CEC value of $7 \mathrm{meq} / 100 \mathrm{~g}$ ".

Practically there is no mineralogical difference between the finer and the coarser varieties of this tuff and the XRD patterns of both show only a major amount of albite and calcite in the coarser fraction (Fig. 6). SEM on the other hand indicated that the tuff is relatively dense with very fine-grained feldspar and illite-smectite particles (Fig. 7a-c).

\section{Petrophysical properties}

Analyses of each of the studied horizons were performed, in order to determine the density and porosity of both, the fine (g1-g5) and the coarse fraction (g1-g7). The results of the determination of the porosity, bulk density, particle density and average pore radius are presented in Table 1 .

As shown in the table, fine-grained horizons have a greater particle density than the coarse-grained, with an average of 2.63 and $2.37 \mathrm{~g} / \mathrm{cm}^{3}$, respectively. The same occurs with the bulk density. A very interesting result and contrary to the expectations is, that the fine variety has a higher porosity and in some horizons even a larger average pore radius than the coarse one. Sedimentary rocks such as siltstones and claystones (similar to the f1-f5 samples) usually have much lower porosities than sandstones (equivalent to g1-g7 samples) because decreasing grain sizes typically correlate with decreasing pore sizes. Studied Tuffs were deposited in principle in a similar way (as pyroclastic and epiclastic rocks) as the above-mentioned sediments, so they are supposed to have similar behaviour, which in this case does not occur. This phenomenon is securely related to the type and distribution of the porosity (micro or capillary porosity), which will be discussed below.

\section{Compressive and tensile strength}

The realized compressive strength tests show that the coarser type of the Loseros Tuff has values that range from 74.3 to $58.0 \mathrm{~N} / \mathrm{mm}^{2}$, where the largest value occurs in the $X$-axis and the lowest value in the $Z$-axis. This condition is certainly associated to the lamination of the tuff. The anisotropy in the coarser Loseros is of $22 \%$ and its modulus of elasticity ranges from 6.3 to $10.0 \mathrm{kN} / \mathrm{mm}^{2}$ with an anisotropic behaviour of around $37 \%$ (Table 2). 
Fig. 6 Diffractograms showing the primary mineralogy of the two varieties of tuffs. Down in blue coarse Loseros, top in red fine Loseros

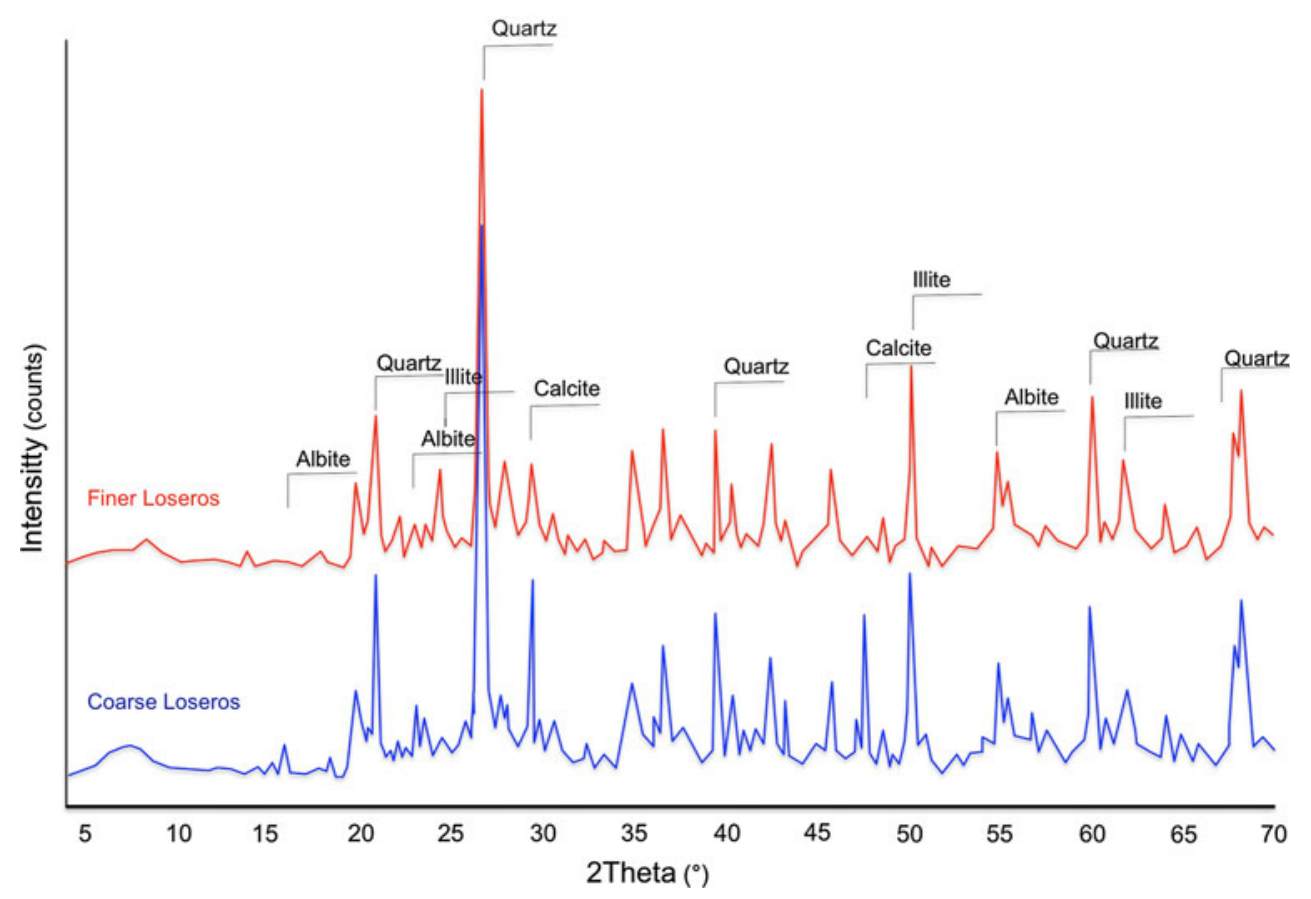

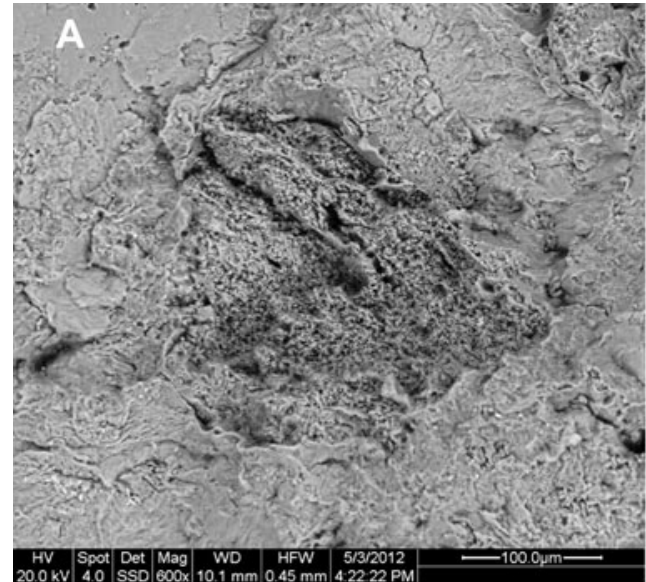

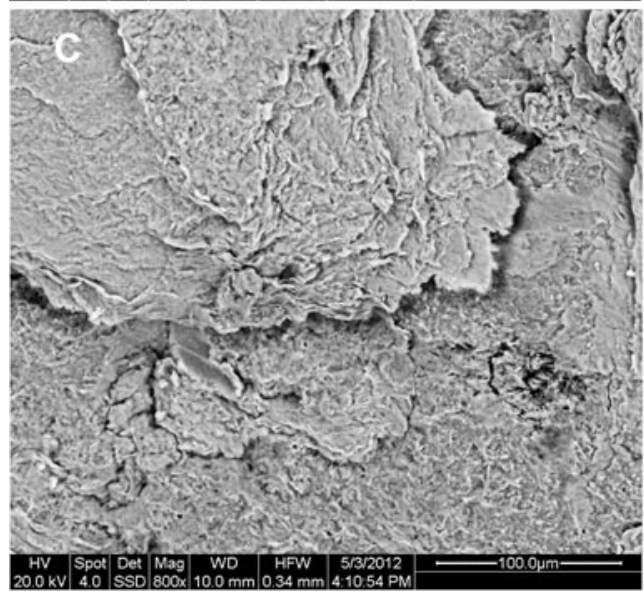

Fig. 7 Typical large pore of relictic crystals in the tuff (a) embedded in a dense matrix as observed by SEM. Tenfold magnification of the central region (b) indicates presence of very fine-grained albite
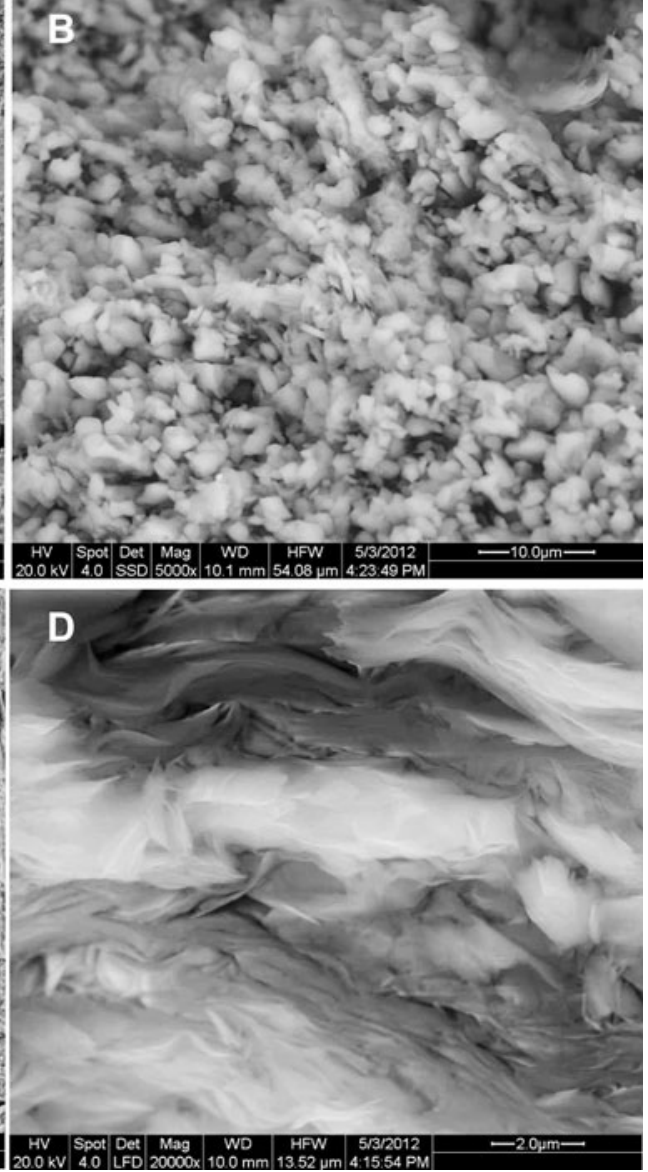

crystals. Clay minerals (illite-smectite) are densely packed (c) and identified under high magnification (d) 
Table 1 Porosity and density properties of the investigated tuff horizons

\begin{tabular}{cccll}
\hline Name & $\begin{array}{l}\text { Porosity } \\
(\text { vol \% })\end{array}$ & $\begin{array}{l}\text { Bulk density } \\
\left(\mathrm{g} / \mathrm{cm}^{3}\right)\end{array}$ & $\begin{array}{l}\text { Particle } \\
\text { density } \\
\left(\mathrm{g} / \mathrm{cm}^{3}\right)\end{array}$ & $\begin{array}{l}\text { Average } \\
\text { pore radius } \\
(\mu \mathrm{m})\end{array}$ \\
\hline Loseros & Formation fine-grained & & \\
1f & 13.05 & 2.30 & 2.65 & 0.030 \\
2f & 12.02 & 2.30 & 2.62 & 0.017 \\
3f & 17.33 & 2.20 & 2.66 & 0.030 \\
4f & 15.12 & 2.22 & 2.62 & 0.020 \\
5f & 17.41 & 2.16 & 2.61 & 0.037 \\
Loseros Formation coarse-grained & & \\
1g & 10.05 & 2.17 & 2.42 & 0.009 \\
2g & 8.19 & 2.16 & 2.35 & 0.08 \\
3g & 6.79 & 2.20 & 2.36 & 0.008 \\
4g & 9.83 & 2.21 & 2.46 & 0.07 \\
5g & 7.70 & 2.13 & 2.30 & 0.006 \\
6g & 8.89 & 2.13 & 2.33 & 0.011 \\
7g & 10.50 & 2.17 & 2.42 & 0.05 \\
\hline
\end{tabular}

Table 2 Tensile and compressive strength as well as the elastic modulus of the studied tuffs

\begin{tabular}{|c|c|c|c|c|c|c|}
\hline \multirow[t]{2}{*}{$\begin{array}{l}\text { Loseros } \\
\text { Formation } \\
\text { tuff type }\end{array}$} & \multicolumn{2}{|c|}{$\begin{array}{l}\text { Tensile strength } \\
\text { (Mpa) }\end{array}$} & \multicolumn{2}{|c|}{$\begin{array}{l}\text { Compressive } \\
\text { strength } \\
\left(\mathrm{N} / \mathrm{mm}^{2}\right)\end{array}$} & \multicolumn{2}{|c|}{$\begin{array}{l}\text { E-modulus } \\
\left(\mathrm{kN} / \mathrm{mm}^{2}\right)\end{array}$} \\
\hline & Fine & Coarse & Fine & Coarse & Fine & Coarse \\
\hline$X$ & $59.19^{\mathrm{a}}$ & $66^{\mathrm{a}}$ & $50.30^{\mathrm{b}}$ & 74.26 & nd & 10.00 \\
\hline$Y$ & $41.07^{\mathrm{a}}$ & nd & $42.26^{\mathrm{b}}$ & 66.90 & nd & 9.86 \\
\hline$Z$ & $30.6^{\mathrm{a}}$ & $50.13^{\mathrm{a}}$ & $57.27^{\mathrm{b}}$ & 57.98 & nd & 6.26 \\
\hline Anisotropy (\%) & 48.3 & 24.0 & 26.2 & 21.9 & nd & 37.4 \\
\hline
\end{tabular}

nd not detectable

${ }^{a}$ Wedekind et al. (this issue)

b Sánchez González (2004), p 93

The uniaxial compressive strength of the finer Loseros Tuff ranges from 57.3 to $42.3 \mathrm{~N} / \mathrm{mm}^{2}$, with an anisotropy of $26 \%$. Contrary to the coarser variety here the greatest value of compression occurs in the direction of the $Z$-axis and the smallest value in the direction of the $Y$-axis (Table 2), which can be explained by the much finer lamination in the Loseros Tuff (presented as laminae), and therefore the sample appears more homogeneous.

Measured tensile strength values follow the same trend as the compression test, where the higher values occur in the coarse variety. The tensile strength values of the coarser Loseros Tuff range from 66.0 to $50.1 \mathrm{Mpa}$, with an anisotropy of $24 \%$. The fine-grained Loseros show a maximum value of 59.2 and a minimum value of $30.6 \mathrm{Mpa}$ with an anisotropy of $48 \%$.
The obtained data of the strength tests are represented in the Table 2.

\section{Porosity and pore size distribution}

Grain sizes and pore size vary greatly from one horizon to the other. Table 3 shows that the average pore radius is larger in the fine-grained horizons, which influences the effectivity of the porosity. In general the fine-grained variety has a larger effective porosity (average of $16 \%$ ), and even the horizon $5 f$ (Table 4) reaches almost $20 \%$.

Moreover, the coarse variety shows a lower effective porosity with an average of $14 \%$. The horizon $4 \mathrm{f}$ has the lowest effective porosity with only $11 \%$; interestingly this horizon is the one with the coarsest grain size of all samples (Table 4).

Table 3 Pore radii distribution of each of the studied horizons

\begin{tabular}{|c|c|c|c|c|c|}
\hline \multirow[t]{3}{*}{ Sample } & \multicolumn{5}{|c|}{ Pore radii distribution $(\%)$} \\
\hline & \multicolumn{2}{|l|}{ Micropores } & \multicolumn{3}{|c|}{ Capillary pores } \\
\hline & $0.001-0.01$ & $0.01-0.1$ & $0.1-1$ & $1-10$ & $>10$ \\
\hline \multicolumn{6}{|c|}{ Fine-grained Loseros Tuff } \\
\hline $1 \mathrm{f}$ & 13.839 & 76.422 & 7.989 & 0.870 & 0.880 \\
\hline $2 \mathrm{f}$ & 21.168 & 73.168 & 3.349 & 0.930 & 1.430 \\
\hline $3 f$ & 9.912 & 78.966 & 9.662 & 0.870 & 0.590 \\
\hline $4 \mathrm{f}$ & 10.771 & 63.076 & 23.842 & 1.240 & 1.070 \\
\hline $5 f$ & 11.970 & 65.410 & 20.700 & 0.820 & 1.100 \\
\hline \multicolumn{6}{|c|}{ Coarse-grained Loseros Tuff } \\
\hline $1 \mathrm{~g}$ & 32.13 & 59.42 & 5.20 & 1.34 & 1.90 \\
\hline $2 \mathrm{~g}$ & 8.659 & 68.93 & 17.57 & 4.83 & - \\
\hline $3 g$ & 54.46 & 35.87 & 5.100 & 1.54 & 3.030 \\
\hline $4 \mathrm{~g}$ & 10.491 & 52.66 & 31.47 & 5.37 & - \\
\hline $5 \mathrm{~g}$ & 48.09 & 43.47 & 5.88 & 1.09 & 1.47 \\
\hline $6 \mathrm{~g}$ & 32.79 & 53.44 & 7.18 & 4.54 & 2.04 \\
\hline $7 \mathrm{~g}$ & 7.56 & 54.70 & 30.89 & 4.82 & 2 \\
\hline
\end{tabular}

Table 4 Effective porosity of each of the studied horizons

\begin{tabular}{|c|c|c|c|}
\hline \multicolumn{4}{|c|}{ Effective porosity (\%) } \\
\hline \multicolumn{2}{|c|}{ Fine-grained Loseros Tuff } & \multicolumn{2}{|c|}{ Coarse-grained Loseros Tuff } \\
\hline 1f & 13.27 & $1 \mathrm{~g}$ & 14.60 \\
\hline $2 \mathrm{f}$ & 15.53 & $2 \mathrm{~g}$ & 15.09 \\
\hline $3 \mathrm{f}$ & 18.35 & $3 g$ & 13.25 \\
\hline $4 \mathrm{f}$ & 16.28 & $4 \mathrm{~g}$ & 11.54 \\
\hline $5 f$ & 19.37 & $5 \mathrm{~g}$ & 15.31 \\
\hline \multirow[t]{3}{*}{ Average } & 16.56 & $6 \mathrm{~g}$ & 18.34 \\
\hline & & $7 \mathrm{~g}$ & 14.22 \\
\hline & & Average & 14.62 \\
\hline
\end{tabular}




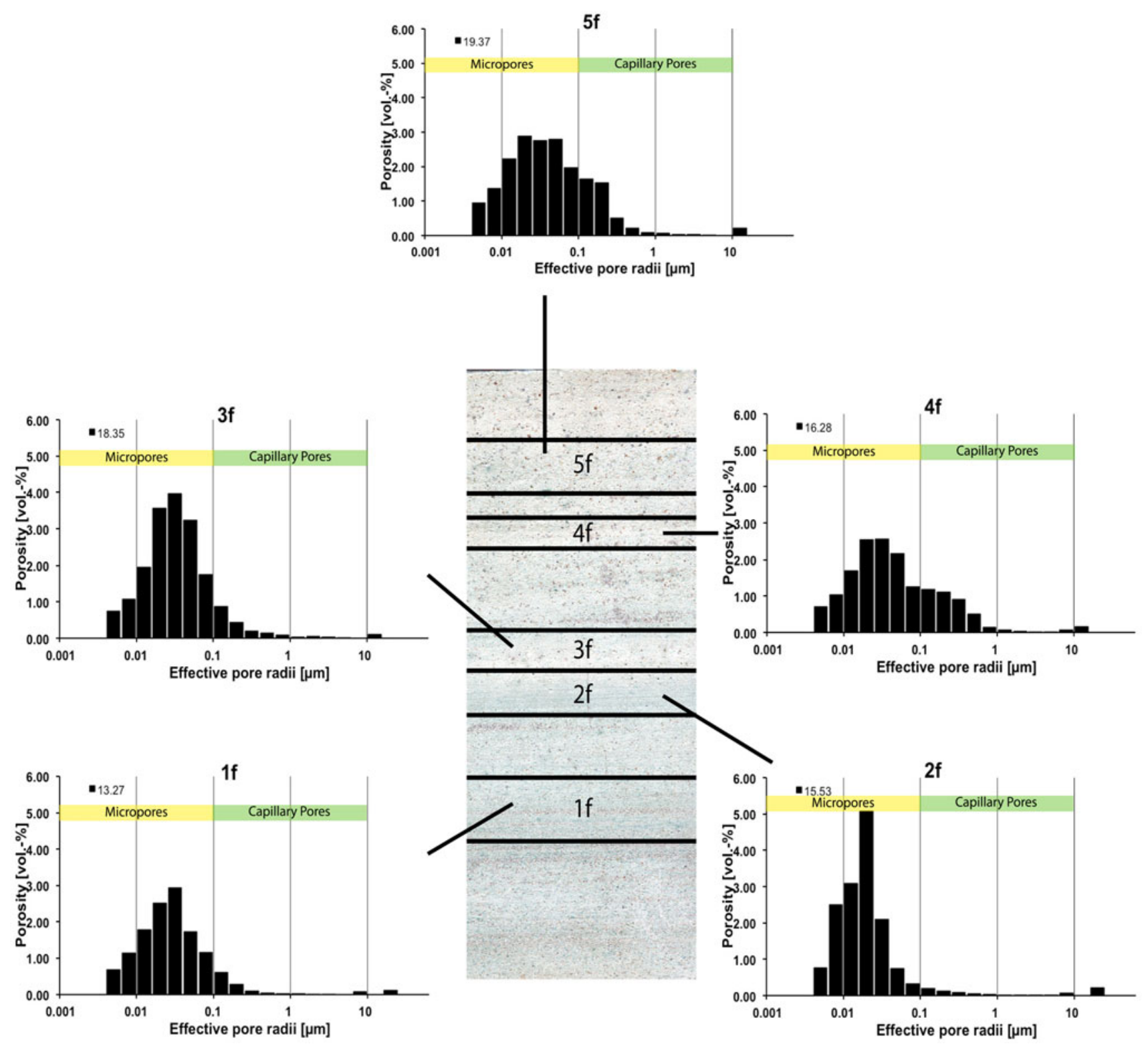

Fig. 8 Pore radii distribution of the different studied horizons of the fine Loseros variety

The distribution of the pores in both varieties is preferably unequal unimodal (Figs. 8, 9). Most of the studied horizons are dominated by micropores with pore sizes ranging from 0.001 to $0.1 \mu \mathrm{m}$ (Table 3; Figs. 8, 9). Horizons $1 \mathrm{f}$ and $2 \mathrm{f}$ contain practically only microporosity (76.4 and $78.9 \%$, respectively). These are also the horizons with the finest grain sizes (Fig. 7). Moreover, in the horizons of the coarse-grained variety $(1 \mathrm{~g}-7 \mathrm{~g})$ the microporosity also dominates; however, absolute percentages are smaller. Horizons $4 \mathrm{~g}$ and $7 \mathrm{~g}$ reach high values of about $30 \%$ capillary porosity and as expected these horizons have the coarsest grain size (Table 3; Fig. 9). Horizon $3 \mathrm{~g}$ has the widest pore size distribution, including more than $3 \%$ of pores $>10 \mu \mathrm{m}$ and the horizon $4 \mathrm{~g}$ includes more than $5 \%$ of capillary pores in the size range of $1-10 \mu \mathrm{m}$.
Sánchez González (2004) reported water absorption values of the fine-grained Loseros Tuff of around $0.8-2.4 \%$ and for the coarser type the values varies from 6.3 to $6.5 \%$. Wedekind et al. (2012a, b), reported absorption values of $0.1 \mathrm{~kg} / \mathrm{m}^{2} \sqrt{h}$, for the fine-grained tuff (see also Wesche 1996).

\section{Water transport properties}

The water transport mechanisms in porous materials are important properties that influence dilatation, swelling, and weathering. The capillary water absorption measured was dependent on the three principal directions $(X, Y, \mathrm{Z})$ on sample cubes of $65 \mathrm{~mm}$ length. The cubes were set with the bottom 


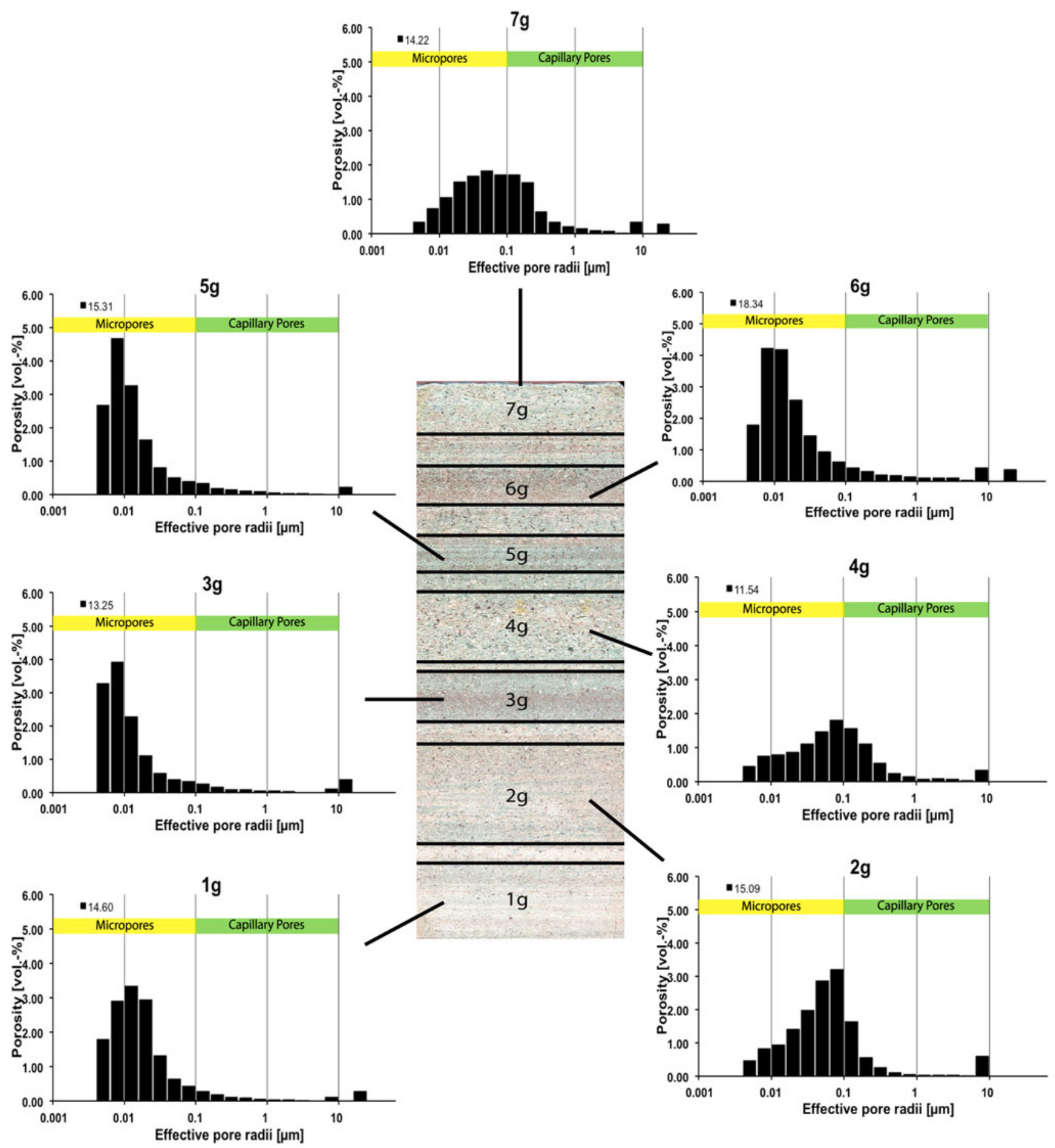

Fig. 9 Pore radii distribution of the different studied horizons of the coarse Loseros variety

plane into water and the weight increase over time was measured. On average both varieties have a low water uptake coefficient of $0.04 \mathrm{~kg} / \mathrm{m}^{2} \sqrt{h}$ for the coarse variety and $0.057 \mathrm{~kg} / \mathrm{m}^{2} \sqrt{h}$ for the fine variety. The coarse variety shows an anisotropy of $46 \%$ and the fine variety of $43 \%$. Both varieties have different vapour diffusion resistances. The coarse variety has a resistance, which is more than a factor of two larger than the fine one. The fine variety has an averaged vapour diffusion resistance value of 26.3 with an anisotropy of $36 \%$ while the $\mu$ value with 57.3 and an anisotropy of $39 \%$ for the fine variety nearly is three times higher. The calculated water absorption coefficient ( $w$ value) and the water vapour diffusion resistance value ( $\mu$ value) are given in Table 5 for all directions. 
Table 5 Moisture transport properties of the investigated tuff horizons

\begin{tabular}{lll}
\hline & Fine variety & Coarse variety \\
\hline$w$ value $\left(\mathrm{kg} / \mathrm{m}^{2} \sqrt{h}\right)$ & & \\
$X$ & 0.077 & 0.026 \\
$Y$ & 0.048 & 0.044 \\
$Z$ & 0.050 & 0.045 \\
Average $\varnothing$ & 0.057 & 0.039 \\
$A(\%)$ & 43 & 46 \\
$\mu$ value & & \\
$X$ & 23.87 & 64.5 \\
$Y$ & 21.48 & 40.93 \\
$Z$ & 33.57 & 66.7 \\
Average $\varnothing$ & 26.30 & 57.37 \\
$A(\%)$ & 36 & 39 \\
\hline
\end{tabular}

Anisotropy $A=n_{\max }-n_{\min } / n_{\max } \times 100$

Petrophysical studies conducted on the tuffs shown a relationship between the parameters porosity, pore radius, pore size and pore distribution. The finer variety has a greater average pore radius, which remains very regular in the different horizons and which is located practically always in the area of microporosity (Table 3; Fig. 8) On the other hand, the average value in the coarse-grained variety is smaller (Table 3), but its distribution is wider and includes horizons with an average pore radius greater than any horizon of the fine variety (g2, g4, g7), but nevertheless it has horizons with a very small average close to zero (g3 and g5) (Fig. 9).

\section{Moisture properties (hygric and hydric expansion)}

In order to probe the response in presence of hygric moisture (related to the relative humidity $\mathrm{RH}$ ) and hydric moisture (under water immersion) tests were performed with both tuff varieties. In order to investigate each horizon individually, the realized experiments were conduced only in the $X$-axis (parallel to stratification), and after that tests in the direction of the $Z$-axis of each variety were implemented, which includes all studied horizons together.

The behaviour of the hygric dilatation in the $X$-axis direction both in the finer as in the coarser variety was very discrete and the values reach scarcely the expansions of $0.05 \mathrm{~mm} / \mathrm{m}$ (finer Loseros) to up $0.1 \mathrm{~mm} / \mathrm{m}$ (coarser sample). The maximum values were reached at a relative humidity of $95 \%$.

In order to study the moisture anisotropy, the direction perpendicular to the $Z$-axis of the coarse-grained variety was also measured (Fig. 10). Results indicate that the hygric expansion in the direction of the $Z$-axis was slightly

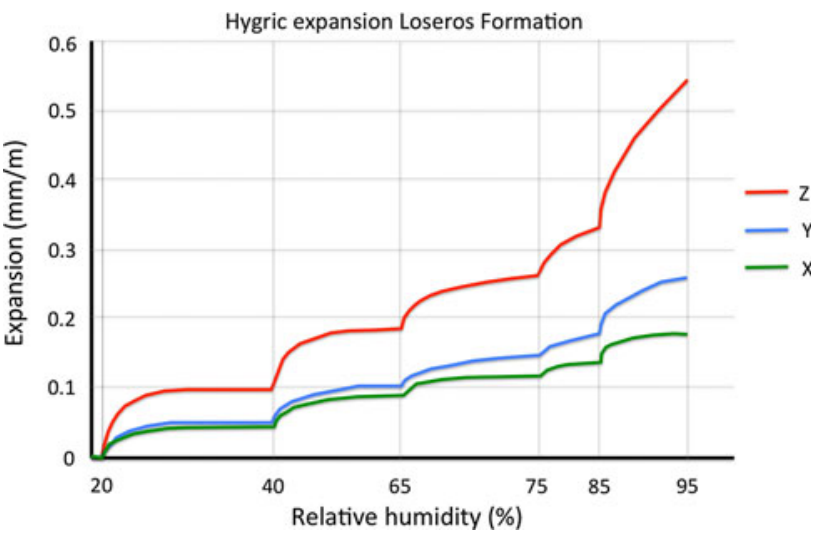

Fig. 10 Moisture expansion depending on relative humidity stages (hygric)

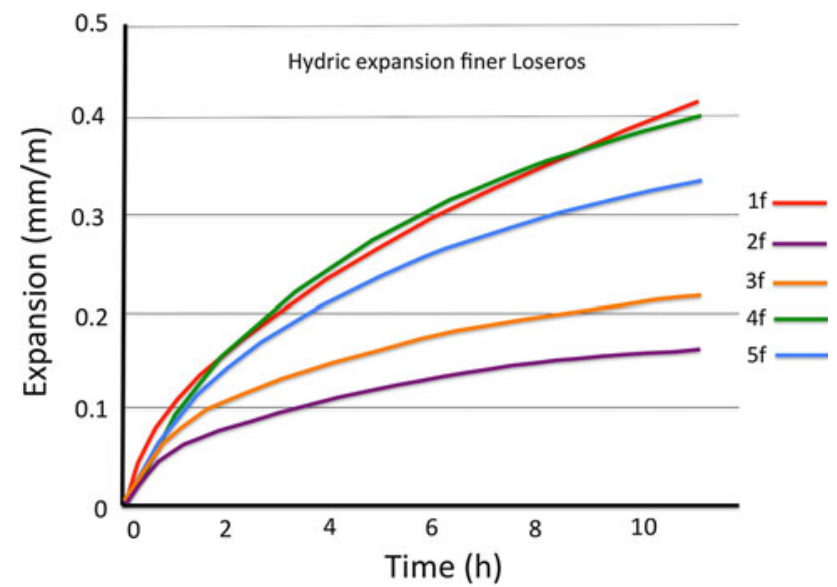

Fig. 11 Moisture expansion under water-saturated conditions (hydric) of the fine Loseros parallel to the lamination ( $X$-direction)

higher than in the previously measured direction of the $X$-axis. Hygric expansion values had a maximum of $0.54 \mathrm{~mm} / \mathrm{m}$ through the lamination (Fig. 10).

The fine-grained horizons were then tested under watersaturated conditions giving smaller values for the hydric than for the hygric experiments (Fig. 11). In the direction of the $X$-axis were recognized values between $0.17 \mathrm{~mm} / \mathrm{m}$ in the horizon $2 \mathrm{f}$ up to $0.42 \mathrm{~mm} / \mathrm{m}$ in the $1 \mathrm{f}$ horizon. Interestingly, the 1f horizon has the smallest effective porosity with $13 \%$ while the grain size (very fine sand) was the coarsest of all horizons examined in this variety (Fig. 11), but still the dilatation was not very pronounced.

The same experiment was performed in the axial direction $X$ of the horizons of the coarse-grained variety, too. Six of the seven horizons show moderate responses to water immersion, with expansion values ranging from $0.17 \mathrm{~mm} / \mathrm{m}$ in horizon $5 \mathrm{~g}$ to $0.35 \mathrm{~mm} / \mathrm{m}$ in horizon $3 \mathrm{~g}$ (Fig. 12). The hydric expansion values of these six samples were comparable to the fine variety except one particular horizon $(4 \mathrm{~g})$ with a much larger expansion and a dilatation 


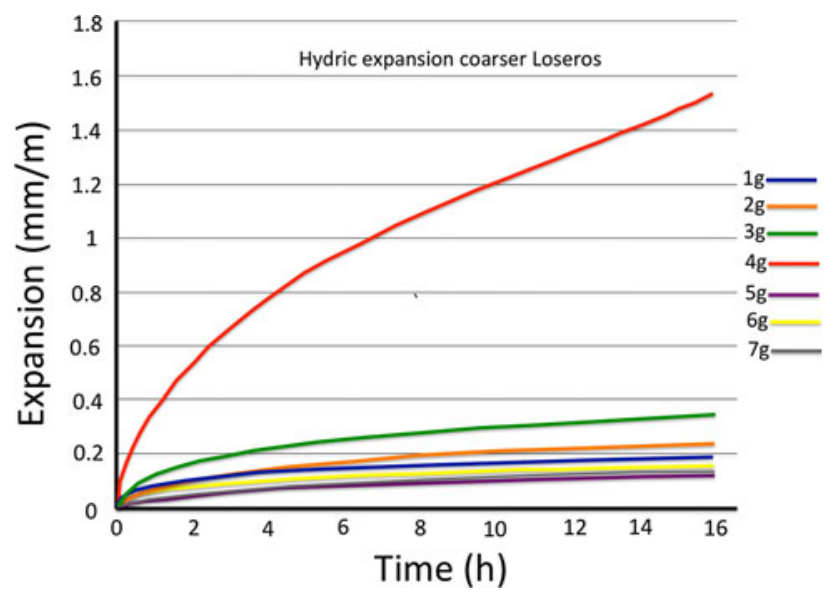

Fig. 12 Moisture expansion under water-saturated conditions (hydric) of the coarse Loseros parallel to the lamination ( $X$-direction)

value of $1.55 \mathrm{~mm} / \mathrm{m}$ (Fig. 12). The pronounced hydric expansion value of horizon $4 \mathrm{~g}$ can be explained by (1) the highest average pore radius value (Table 1); (2) the highest absolute capillary porosity (Table 3); and (3) by the coarsest grain size (Fig. 12), however, on the other hand horizon $4 \mathrm{~g}$ has the smallest effective porosity of all the analysed horizons (Table 4).

The same kind of experiment was repeated, but this time the hydric expansion of the coarse-grained variety was measured along the direction of the $Z$-axis (perpendicular to lamination). This analysis sums up the properties of the horizons $2 \mathrm{~g}, 3 \mathrm{~g}, 4 \mathrm{~g}, 5 \mathrm{~g}$ and $6 \mathrm{~g}$ together. The measured hydric expansion along the Z-axis (Fig. 13) that results from subjecting the sample under water-saturated conditions shows very interesting aspects. Initially the sample shows a very regular trend with expansion values up to $1.44 \mathrm{~mm} / \mathrm{m}$ during the first $16 \mathrm{~h}$ of the experiment, but immediately after this point an extremely quick expansion with an increase of almost a factor of two in a span of about $2-3 \mathrm{~h}$ was detected. Measured values ranged from 1.5 to $3.5 \mathrm{~mm} / \mathrm{m}$ and the slope of the curve was almost vertical (Fig. 13).

This is again followed by a weaker increase, with values ranging from 3.5 to $4.1 \mathrm{~mm} / \mathrm{m}$ expansion in approximately $6 \mathrm{~h}$ (Fig. 13). After $26 \mathrm{~h}$ of experiment, the sample began to stabilize and eventually stop its expansion (Fig. 13). Obtained hydric expansion values exceeded markedly the values of expansion of the horizons studied individually and that represented probably the addition of each expansion values of each horizon together.

A fact that should be noted is that at the end of the experiment a thin layer of sediment was deposited at the bottom of the vessel where the sample was immersed for carrying out the experiment. After the end of the experiment crumbling was recognized and eventually the sample

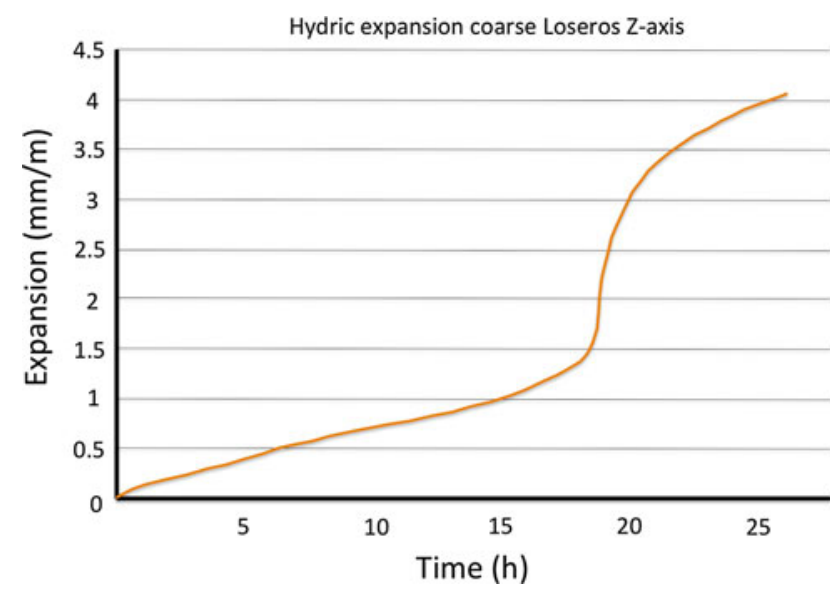

Fig. 13 Moisture expansion under water-saturated conditions (hydric) of the coarse Loseros perpendicular to the lamination ( $Z$ direction)

started to break. The collapse phenomenon (scaling and crumbling) was not observed in any other test used to check the moisture properties of the Loseros Tuff, but it was widely recognized during the fieldwork directly from the constructions.

It must be noted the main damage in the sample, including the collapse and breakup happened on the horizon $4 \mathrm{~g}$, in which the lack of cementation between the grains was clearly recognizable, which caused the formation of scaling and crumbling.

\section{Discussion and conclusions}

The observed differences in both varieties of the Loseros Tuff allow drawing some conclusions about their weathering and deterioration behaviour that affect them. The causes of the deterioration cannot be attributed to a single factor but it includes a number of causes including composition, texture and physical properties (see also Yavuz 2006; Klinkenberg et al. 2009).

It was initially recognized in the field that the most problems do not occur in fine-grained layers but in areas where the grains and crystals have sizes around the sand fraction. The grain shapes are mostly angular to sub-angular and the fabric varies between matrix supported and grain supported, which depends on the content of matrix. The matrix in this case was identified as a mixture of volcanic glass, silt up to clay-sized particles and calcite. It is already known that fine-grained rocks composed of particles in the clay-silt fraction have better consolidation than rocks with particles of the sand fraction (Hjulström 1935; Sundborg 1956). This obviously plays an important role during the weathering of the Loseros Tuff, but another important factor that must to be considered is the composition of the 
cement, which keeps the grains bonded to one another. As seen, there is a high amount of calcium carbonate (calcite, $\mathrm{CaCO}_{3}$ ) in the matrix and this mineral may be the reason for the observed differences because calcite is relatively soluble under weathering conditions, which can be probed even with normal meteoric water.

Therefore, it is likely to assume that the matrix may have been partially dissolved, which greatly reduced the cohesion of the particles promoting flaking and crumbling The petrographic study also showed a high content of glass micro-shards and ash in the matrix and its consolidation (collapsing) with the grain crystal rock fragments and other lithic fragments depends of the grade of compaction between them, but under the microscope it looks weakly welded to the grains (Fig. 5).

Other important factors are the porosity and the average radius of the different horizons, which are related to the water transport in the rock. It is known that volcanic rocks, especially tuff rocks show a large variability in the porosity (Siegesmund and Dürrast 2011), and the effective porosity in the Loseros Tuff varies from 11 to $20 \%$ but almost always with an average radius in the micropore size (Klopfer 1985). The fact that the coarse-grained 4g horizon has the largest pore radius and at the same time the lowest effective porosity shows that the pores are not well interconnected between each other, which allow the water uptake but restrict its transport (Kraus 1985; Graue et al. 2011). It seems that in the fine-grained horizons the similarities between the pore sizes and grain sizes (well-sorting) allow for a better interconnection between the pores.

The results of the moisture hygric dilatation in the finegrained variety show a normal trend related to its average pore radius and effective porosity, mainly because the water uptake and its transport occurs almost exclusively across the micropores and restricts the contact between the water vapour and the swellable clay minerals (Larsen and Cady 1969; Siegesmund and Dürrast 2011). A very different behaviour was observed when the coarse-grained tuff was saturated in water. On the one hand, an initial moderate expansion can be seen, which means that moisture is introduced slowly into the sample causing a gradual and slow expansion. At the same time the water, which now fills the low primary effective porosity, begins to dissolve the carbonate matrix, causing a secondary porosity, releasing new spaces (pores) where the water now invaded the rock. This process of dissolution was clearly identifiable in the hydric test. After the dissolution, moisture and water contacted the clay minerals in the matrix that previously had no interaction with it and this process was accompanied by a sudden expansion. The hydric dilatation values reached very high values, which also caused disaggregation of crystals and fragments that were cemented.
The dissolution of the matrix in this case was irreversible because the cement material dissolved out in the infiltrating water flows, as happens with outcropped natural rocks, even in buildings stones. The time required for the expansion varies greatly according to the rock type and it depends mainly on the pore space properties. Rocks with a good connected pore network and higher porosities have faster expansion and rocks with less connected pores and lower porosity values show low expansion velocities (Siegesmund and Dürrast 2011; Morales Demarco et al. 2007; Ruedrich et al. 2005). The Loseros Tuff shows both behaviours (velocities), which can be only explained with a change in the pore space properties.

Finally, hydric dilatation is another process that is not necessarily irreversible, but when it happens, it contributes to the separation of the crystals and rock fragments especially if the cement is partially dissolved, causing the collapse of the rock, as happened during our experiments.

Acknowledgments The first author conducted the laboratory work in the Department of Structural Geology and Geodynamics, Geoscience Centre, University of Göttingen, thanks to a grant from the DAAD (German Academic Exchange Service). We are grateful to Annette Süssenberger, Günter Tondock, Harald Tonn and Sergio Molina for the technical and laboratory support.

Open Access This article is distributed under the terms of the Creative Commons Attribution License which permits any use, distribution, and reproduction in any medium, provided the original author(s) and the source are credited.

\section{References}

Brakel J, van Modry S, Svata M (1981) Mercury porosimetry: state of the art. Powder Technol 29:1-12

Buchanan LJ (1980) Ore-controls of a fossil geothermal system: the Las Torres Mine, Guanajuato, México, private report

Edwards JD (1956) Estudio sobre algunos de los Conglomerados Rojos del Terciario Inferior del centro de México, XX Congreso Geológico Internacional, México 1956

Fisher RV (1961) Proposed classification of volcaniclastic sediments and rocks. Geol Soc Am Bull 80:1-8

Fisher RV, Schmincke H-U (1984) Pyroclastic rocks. Springer, New York, p 472

Graue B, Siegesmund S, Middendorf B (2011) Quality assessment of replacement stones for the Cologne Cathedral: mineralogical and petrophysical requirements. Environ Earth Sci 63:1799-1822

Hjulström F (1935) Studies in the morphological activity of rivers as illustrated by River Fyris. Bull Geol Inst Upps 25:221-528

Klinkenberg M, Rickertsen N, Kaufhold S, Dohrmann R, Siegesmund S (2009) Abrasivity by bentonite dispersions. Appl Clay Sci 46:37-42

Klopfer H (1985) Feuchte. In: Lutz P et al (eds) Lehrbuch der Bauphysik. Teubner, Stuttgart, pp 329-472

Kraus K (1985) Experimente zur immissionsbedingten Verwitterung der Naturbausteine des Kölner Doms im Vergleich zu deren Verhalten am Bauwerk. Dissertation, University of Cologne, p 208

Larsen TD, Cady PD (1969) Identification of frost susceptible particles in concrete aggregates, National Cooperative Research 
Program, Report 66. Highway Research Board, Washington, DC, p 62

Le Maitre RW, Streckeisen A, Zanettin B (eds) (2004) Igneous rocks: a classification and glossary terms. Cambridge University Press, Cambridge

Monod O, Lapierre E, Chiodi M, Martínez-Reyes J, Calvet P, OrtizHernández LE, Zimmermann JL (1990) Reconstitution d'un arc insulaire intra-océanique au Mexique central: la sécuence volcano- plutonique de Guanajuato (Crétace Infériur). CR Acad Sci Paris 310(11):45-51

Morales Demarco M, Jahns E, Ruedrich J, Oyhantcabal P, Siegesmund S (2007) The impact of partial water saturation on rock strength: an experimental study on sandstone. Zeitschrift Deutsche Geologische Gesellschaft, Band 158:869-882

Nieto-Samaniego AF, García-Dobarganes, Aguirre-Maese AL (1992) Interpretación estructural de los rasgos geomorfológicos principales de la Sierra de Guanajuato. Universidad Nacional Autónoma de México, Instituto de Geología, Revista, 10/1, p 25

Ortiz-Hernández LE, Chiodi M, Lapirre H, Monod O, Calvet P (1992) $\mathrm{El}$ arco intraoceánico alóctono (Cretácico inferior) de Guanajuato-Características petrográficas, geoquímicas, estructurales e isotópicas del complejo filoniano y de las lavas basálticas asociadas; implicaciones geodinámicas. Universidad Nacional Autónoma de México, Instituto de Geología, Revista, 9/2, pp 126-145

Rüdrich J, Bartelsen T, Dohrmann R, Siegesmund S (2011a) Moisture expansion as a deterioration factor for sandstone used in buildings. Environ Earth Sci. 63:1545-1564

Rüdrich J, Kirchner D, Siegesmund S (2011b) Physical weathering of building stones induced by freeze-thaw action: a laboratory long-term study. Environ Earth Sci 63:1573-1586
Ruedrich J, Kirchner D, Seidel M, Siegesmund S (2005) Deterioration of natural building stones induced by salt and ice crystallisation in the pore space as well as hygric expansion processes. In: Siegesmund S, Auras M, Ruedrich J, Snethlage R (eds) Geowissenschaften und Denkmalpflege. Zeitschrift Deutsche Geologische Gesellschaft 156/1:59-73

Sánchez González JA (2004) Inventario físico de los recursos minerales del municipio Guanajuato, Gto. Consejo de Recursos Minerales, Dirección de Minas de Guanajuato

Siegesmund S, Dürrast H (2011) Physical and mechanical properties of rocks. In: Siegesmund S (ed) Stone in architecture, 4th edn. Springer, Berlin, pp 97-225

Siegesmund S, Snethlage R (2011) Stone in architecture, 4th edn. Springer, Berlin, p 552

Sundborg A (1956) Some aspects of fluvial sediments and fluvial morphology, 1. General views and graphic methods. Geogr Ann 49:333-343

Wedekind W, López-Doncel R, Dohrmann R, Siegesmund S (2012a) Weathering and deterioration of volcanic tuff rocks used as natural building stone caused by moisture expansion. Geophysical Research Abstracts, vol 14, EGU2012-3816, 2012 EGU General Assembly 2012

Wedekind W, López-Doncel R, Dohrmann R, Kocher M, Siegesmund $S$ (2012b) Weathering and deterioration of volcanic tuff rocks used as building stone causes by moisture expansion. Environ Earth Sci (this issue)

Wesche K (1996) Baustoffe für tragende Bauteile Grundlagen 1. Bauverlag, Wiesbaden, p 145

Yavuz AB (2006) Deterioration of the volcanic kerb and pavement stones in a humid environment in the city centre of Izmir, Turkey. Environ Geol 51:211-227 